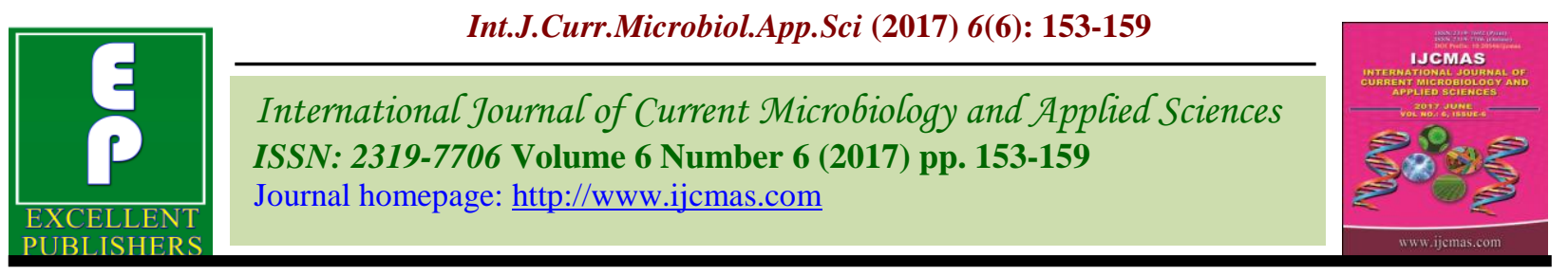

Original Research Article

https://doi.org/10.20546/ijcmas.2017.606.018

\title{
Genetical Studies on Assessment of Heterosis for Fruit Yield and Attributing Characters in Okra [Abelmoschus esculentus (L.) Moench]
}

\author{
Tapas Paul $^{1 *}$, R.T. Desai ${ }^{2}$ and R. Choudhary ${ }^{3}$ \\ ${ }^{1}$ Department of Genetics and Plant Breeding, ICAR Research Complex for NEH Region, \\ Tripura Centre, Lembucherra, 799210, India \\ ${ }^{2}$ Department of Genetics and Plant Breeding, Navsari Agricultural University, \\ Navsari, Gujarat, 396450, India \\ ${ }^{3}$ Department of Genetics and Plant Breeding, G.B. Pant University of Agriculture and \\ Technology, Pantnagar, India \\ *Corresponding author
}

\section{A B S T R A C T}

\section{Keywords}

Standard heterosis,

Heterobeltiosis,

Dialliel,

Better Parent,

Okra

Article Info

Accepted:

04 May 2017

Available Online:

10 June 2017
Fifty five crosses from $11 \times 11$ diallel excluding reciprocals were studied to assess the magnitude of heterosis over Better parent (BP) and standard check (SC) for fruit yield and its components in Okra [Abelmoschus esculentus (L) Moench]. Analysis of variance manifested highly significant differences for different characters which indicating the considerable genetic diversity among the material studied. For number of fruit per plant hybrids HRB-55 x AOL-09-17(87.58\%), JOL-09-8 x AOL-09-17 (71.17\%) and AOL-0917 x JOL-09-7(62.48\%) depicted significant heterosis over better parent. For standard heterosis the crosses HRB-55 x AOL-09-17(71.08\%), JOL-09-8 x AOL-09-17(49.37\%), AOL-09-17 x JOL-09-7(41.78\%) and JOL-55-3 x HRB-55(26.99\%) exhibited most superior performance. For total fruit yield per plant heterobeltiosis ranged from -24.62 to 53.93 and total 15 hybrids showed positive response and highest performing hybrids are JOL-09-8 x JOL-09-7 (53.93\%), JOL-09-8 x AOL-09-17 (37.99\%) and JOL-09-12 x AOL-09-2 (37.76\%). The values for standard heterosis ranged from -12.00 to 53.88 per cent and Seventeen crosses exhibited positive significant standard heterosis. The cross HRB-55 x AOL-09-17 exhibited the highest magnitude of heterosis to the extent of 53.88 per cent over standard check for fruit yield per plant. Other best performing crosses on the basis of merit are HRB-55 x AOL-09-17 (53.88 \%), JOL-09-8 x AOL-09-17 (48.83\%) and AOL-09-17 x JOL-09-7(46.17\%) respectively and the crosses can be used for exploitation of hybrid vigor on commercial scale. The study reveals good scope for exploitation of heterosis in okra for high yield.

\section{Introduction}

Okra [Abelmoschus esculentus (L.) Moench] is a versatile vegetable crop from Malvaceae family and is comprising of valuable nutrients. Okra is the important vegetable crop of India, is grown successfully during both summer and rainy seasons for its green tender fruits. Okra is rich in various nutrients and the average nutritive value (ANV) of okra is 3.21 per cent Bhendi has a vast potential as one of the foreign exchange earner and accounts for about $60 \%$ of the export of fresh vegetables. The ease in emasculation, high fruit set, short duration makes commercial exploitation of heterosis in okra easy. For 
genetic improvement of the crop genetic diversity study is prerequisite which is followed by hybridization to make cross combinations to identify suitable crosses and parents for exploition of heterosis. Exploitation of hybrid vigour is an important tool for making genetical improvement of yield and its attributing characters in okra (Wammanda et al., 2010). Heterosis for yield and yield attributing traits are reported by several other researchers (Eswaran et al., 2013; Ramya et al., 2010; Kumar et al., 2010; Nagesh et al., 2014). The magnitude of heterosis for yield and its components provides a basis for determining genetic diversity and also serves as a guide for the choice of desirable parents for developing superior F1 hybrids to exploit hybrid vigour. Knowledge of heterosis of yield and its component characters should be placed greater emphasis for the improvement for this crop. Keeping this in view the objective of the present investigation was to assess the magnitude of heterosis for fruit yield and its components in okra.

\section{Materials and Methods}

The present study consists of 11 different okra genotypes viz., AOL-09-13, JOL-55-3, AOL08-5, JOL-1, JOL-09-8, JOL-09-12, HRB-55, JOL-08-16, AOL-09-17, AOL-09-2, JOL-097. The genotypes are crossed in diallel fashion excluding reciprocals to produce 55 hybrids in late kharif 2011. These 55 F1 hybrids evaluated along with their 11 parents and check GOH-2 in Randomized Block Design in three replications during late kharif 2012 at university farm, Department of Botany, Navsari Agricultural University, Navsari.

Each plot consisted of a single row of 10 plants. Inter and intra row spacing was kept 60 and $30 \mathrm{~cm}$, respectively. Agronomic practices followed as per the standard recommendation and sufficient protection measures were taken to raise a healthy crop stand. The different 11 quantitative characters like Days to First Flowering, Number of primary branches per plant, Plant Height, Internode Length, Fruit Length, Fruit Diameter, Number of Ridges on fruit, Fruit Weight, Number of Fruits per plant and Fruit Yield per Plant has been recorded. The various observations were recorded on five competitive plants in each plot leaving border ones. The magnitude of heterosis was calculated as per the standard procedure and data were analysed according to the method suggested by Kempthorne (1957).

\section{Results and Discussion}

Analysis of variance (Table 1) showed significant differences for all the characters which indicated the presence of appreciable genetic diversity for the traits under study and the hybrid with high value of heterosis can be further exploited. The hybrids are normally assessed in terms of per cent increase over better parent and standard check variety.

The range of heterosis over better parent and standard check found to be different for all the characters under study (Table 2). For Days to initiation of flowering significant negative heterobeltiosis was observed for 38 crosses.

All the crosses had significant negative heterotic effect over standard check and the cross AOL-09-13 x JOL-55-3 (-21.85\%) followed by AOL-09-13 x AOL-09-2($20.32 \%)$ and AOL-09-13 x AOL-08-5($19.42 \%$ ) recorded maximum standard heterosis for days to initiation of flowering and can be designated as most early crop. For Number of primary branches, 20 cross combinations showed positive and significant standard heterosis and maximum value was observed for the cross HRB-55 x AOL-09-17 (40.47\%) followed by JOL-09-8 x AOL-09$17(37.08 \%)$ and AOL-08-5 x AOL-09$17(36.73 \%)$ respectively. 
Table.1 Analysis of variance (mean squares) for experimental design for various characters in Okra

\begin{tabular}{|c|c|c|c|c|c|c|c|c|c|c|c|}
\hline $\begin{array}{c}\text { Sources of } \\
\text { variation }\end{array}$ & DF & $\begin{array}{c}\text { Days to } \\
\text { first } \\
\text { flowering }\end{array}$ & $\begin{array}{c}\text { Primary } \\
\text { branches } \\
\text { per plant }\end{array}$ & $\begin{array}{c}\text { Plant } \\
\text { height } \\
(\mathbf{c m})\end{array}$ & $\begin{array}{l}\text { Internodal } \\
\text { length }(\mathrm{cm})\end{array}$ & $\begin{array}{c}\text { Fruit } \\
\text { length } \\
(\mathrm{cm}) \\
\end{array}$ & $\begin{array}{c}\text { Fruit } \\
\text { diameter } \\
(\mathrm{cm})\end{array}$ & $\begin{array}{c}\text { No. of ridges } \\
\text { on fruit }\end{array}$ & $\begin{array}{c}\text { Fruit } \\
\text { weight } \\
\text { (cm) }\end{array}$ & $\begin{array}{c}\text { No of } \\
\text { fruits per } \\
\text { plant }\end{array}$ & $\begin{array}{c}\text { Fruit yield } \\
\text { per plant } \\
(\mathrm{cm})\end{array}$ \\
\hline Replications & 2 & 2.705 & 0.126 & 16.240 & 0.141 & 0.760 & 0.002 & 0.004 & 0.284 & 0.429 & $2353.750^{*}$ \\
\hline Treatments & 65 & $15.695 * *$ & $1.013 * *$ & $290.841 * *$ & $1.164 * *$ & $2.102 * *$ & $0.015 * *$ & $0.149 * *$ & $0.721 * *$ & $19.976^{* *}$ & $3981.156 * *$ \\
\hline Parents & 10 & $30.110^{* *}$ & $1.752 * *$ & $384.243 * *$ & $1.125^{* *}$ & 0.576 & $0.022 * *$ & $0.351^{* *}$ & $0.705 *$ & $4.818 *$ & $2279.462 * *$ \\
\hline Hybrids & 54 & $12.602 * *$ & $0.891 * *$ & $281.690 * *$ & $1.127 * *$ & $20422 * *$ & $0.014 * *$ & $0.114^{* *}$ & $0.736 * *$ & $22.309 * *$ & $3695.200 * *$ \\
\hline $\begin{array}{l}\text { Parent Vs } \\
\text { Hybrids }\end{array}$ & 1 & $38.547 * *$ & 0.238 & 210.949 & $3.540 * *$ & 0.086 & 0.000 & 0.001 & 0.064 & $45.595^{* *}$ & $36439.680 * *$ \\
\hline Error & 130 & 0.999 & 0.142 & 80.133 & 0.127 & 0.451 & 0.001 & 0.004 & 0.327 & 1.977 & 690.507 \\
\hline
\end{tabular}

*.**significant at $5 \%$ and $1 \%$ level, respectively

Table.2 Range of Heterosis and number of hybrids showing significant Heterobeltiosis (HB) and Standard Heterosis ( $\mathrm{SH}$ ) for ten characters under study

\begin{tabular}{|l|l|c|c|c|c|}
\hline $\begin{array}{l}\text { S. } \\
\text { No. }\end{array}$ & Characters & \multicolumn{2}{|l|}{ Range of Heterosis } & \multicolumn{2}{l}{$\begin{array}{l}\text { No. of Hybrids showing significant } \\
\text { and desirable Heterosis }\end{array}$} \\
\hline & & HB & SH & HB & SH \\
\hline 1 & Days to first flowering & -18.68 to 1.95 & -21.85 to -1.75 & 38 & 54 \\
\hline 2 & Primary branches per plant & -39.49 to 15.34 & -30.41 to 40.47 & 0 & 20 \\
\hline 3 & Plant height (cm) & -20.74 to 19.29 & -23.91 to 23.49 & 4 & 4 \\
\hline 4 & Internodal length (cm) & -16.08 to 38.55 & -9.89 to 28.57 & 7 & 27 \\
\hline 5 & Fruit length $(\mathbf{c m})$ & -20.82 to 27.39 & 15.04 to 29.23 & 5 & 5 \\
\hline 6 & Fruit diameter(cm) & -10.75 to 6.94 & -12.22 to 5.76 & 5 & 5 \\
\hline 7 & No. of ridges on fruit & -13.33 to 8.20 & -5.82 to 13.20 & 34 & \\
\hline 8 & Fruit weight $(\mathbf{g})$ & -10.74 to 6.48 & -1.20 to 20.82 & 0 & 10 \\
\hline 9 & No. of fruits per plant & -16.41 to 87.58 & -38.31 to 71.08 & 4 & 4 \\
\hline 10 & Fruit yield per plant $(\mathbf{g})$ & -24.62 to 53.93 & -12.00 to 53.88 & 15 & 17 \\
\hline
\end{tabular}


Table.3 Manifestation of better parent and standard heterosis for other characters in three top crosses most heterotic for fruit yield / plant

\begin{tabular}{|c|c|c|c|c|c|c|}
\hline \multirow[t]{2}{*}{ Characters } & \multicolumn{3}{|c|}{ Better parent heterosis } & \multicolumn{3}{|c|}{ Standard heterosis } \\
\hline & $\begin{array}{c}\text { JOL-09-8 } \\
\text { X } \\
\text { JOL-09-7 }\end{array}$ & $\begin{array}{c}\text { JOL-09-8 } \\
X \\
\text { AOL-09-17 }\end{array}$ & $\begin{array}{c}\text { JOL-09-12 } \\
X \\
\text { AOL-09-2 }\end{array}$ & $\begin{array}{c}\text { HRB-55 } \\
\text { X } \\
\text { AOL-09-17 }\end{array}$ & $\begin{array}{c}\text { JOL-09-8 } \\
\mathrm{X} \\
\text { AOL-09-17 }\end{array}$ & $\begin{array}{c}\text { AOL-09-17 } \\
\text { X } \\
\text { JOL-09-7 }\end{array}$ \\
\hline Days to initiation of flowering & -0.35 & $-6.03 *$ & $-8.76^{* *}$ & -1.75 & $-6.37 * *$ & $-4.38 * *$ \\
\hline $\begin{array}{l}\text { No. of primary branches per } \\
\text { plant }\end{array}$ & -14.01 & -3.38 & 5.80 & $40.47 * *$ & $37.08 * *$ & $35.20 * *$ \\
\hline Plant height & -12.95 & $17.35^{*}$ & -4.30 & $23.49 * *$ & $21.21 * *$ & $19.93 * *$ \\
\hline Internodal length & -12.95 & -3.38 & 8.42 & $10.99 * *$ & $9.89 *$ & 9.34 \\
\hline Fruit length & -6.72 & $18.06^{* *}$ & -4.63 & $29.23 * *$ & $26.79 * *$ & 25.11 \\
\hline Fruit diameter & $-5.55 * *$ & $2.97 *$ & 1.08 & $5.76 * *$ & $2.79 *$ & 1.92 \\
\hline No. of ridges on fruit & -1.56 & $2.96^{* *}$ & $3.59 * *$ & $13.20 * *$ & $14.16 * *$ & $10.51 * *$ \\
\hline Fruit weight & -7.14 & 2.34 & 6.48 & $20.82 * *$ & $14.16 * *$ & $17.27 * *$ \\
\hline No. of fruits per plant & -16.41 & $71.17 * *$ & -13.69 & $71.08 * *$ & $49.37 * *$ & $41.78 * *$ \\
\hline Fruit yield per plant & $53.93 * *$ & $37.99 * *$ & $37.76 * *$ & $53.88 * *$ & $48.83 * *$ & $46.17 * *$ \\
\hline
\end{tabular}

$*, * *$ significant at $5 \%$ and $1 \%$ level, respectively 
For plant height three cross combination showed significant positive standard heterosis over standard check from which the highest value was observed for the cross HRB-55 x AOL-09-17(23.49\%) and the other two are JOL-09-8 x AOL-09-17(21.21\%) and AOL09-17 x JOL-09-7(19.29\%). Out of 55 crosses, HRB-55 x AOL-09-2(28.57 \%), AOL-09-2 x JOL-09-7(26.92 \%) and AOL09-17 x AOL-09-2(26.37\%) manifested highest significant positive standard heterosis for Internodal Length.

The estimate of heterobeltiosis for fruit length varied between -20.82 to 27.39 per cent. Five crosses viz.; JOL-55-3 x HRB-55(27.39\%), HRB-55 x AOL-09-17(20.44 \%), JOL-09-8 x AOL-09-17 (18.16 \%), AOL-09-17 x JOL-097(16.6\%) and JOL-09-12 x HRB-55(13.52 $\%$ showed significant positive heterobeltiosis. On the contrary, 4 crosses exhibited negative heterobeltiosis. The estimates of standard heterosis varied from 15.04 to 29.23 per cent. Four crosses viz.; HRB-55 x AOL-09-17(29.23\%), JOL-09-8 x AOL-09-17(26.79 \%), AOL-09-17 x JOL-097 (25.11\%), and JOL-55-3 x HRB$55(22.74 \%)$ showed significant positive standard heterosis for fruit length.

The hybrids HRB-55 x AOL-09-17 (5.76 \%) exhibited maximum standard heterosis followed by JOL-09-8 x AOL-09-17 (2.79\%) for positive significant heterosis over Fruit Diameter. Eight crosses showed significant positive standard heterosis for number of ridges on fruit and the maximum found in the cross combination HRB-55 x AOL-09$17(13.20 \%)$. The range for standard heterosis for fruit weight was -1.20 to 20.82 per cent. Ten crosses exhibited positive significant standard heterosis for this character. Three most promising crosses showed significant standard heterosis are HRB-55 x AOL-0917(20.82\%), AOL-09-17 X JOL-09$7(17.27 \%)$ and JOL-09-8 $x$ AOL-09$17(14.16 \%)$. Out of 55 cross combinations only 4 registered significant positive heterobeltiosis for Number of Fruits/Plant, of these, three top ranking were HRB-55 $\mathrm{x}$ AOL-09-17(87.58\%), JOL-09-8 x AOL-09-17 $(71.17 \%)$ and AOL-09-17 $x$ JOL-09$7(62.48 \%)$. The minimum and maximum values of standard heterosis for fruits per plant were -38.31 to 71.08 per cent. Only 4 cross combination registered significant positive standard heterosis and they are HRB55 x AOL-09-17(71.08\%), JOL-09-8 x AOL09-17(49.37\%), AOL-09-17 x JOL-09$7(41.78 \%)$ and JOL-55-3 x HRB-55(26.99\%).

For fruit yield per plant, the estimates of heterobeltiosis ranged from -24.62 to 53.93 per cent. Total 15 hybrids depicted significant positive heterosis over better parent. Cross JOL-09-8 x JOL-09-7 (53.93\%) depicted the highest significant positive heterobeltiosis followed by JOL-09-8 x AOL-09-17 (37.99 $\%)$ and JOL-09-12 x AOL-09-2 (37.76 \%). Only one hybrid depicted significant negative heterobeltiosis. The values for standard Heterosis ranged from -12.00 to 53.88 per cent. Seventeen crosses exhibited positive significant standard heterosis out of which three best were HRB-55 x AOL-09-17 (53.88 $\%)$, JOL-09-8 x AOL-09-17 (48.83\%) and AOL-09-17 x JOL-09-7(46.17 \%) (Table 3). On the other hand surprisingly none of the crosses exhibited significant negative heterosis for fruit yield over standard check.

Three best crosses and their percent heterosis over standard check are HRB-55 x AOL-0917 (53.88\%), JOL-09-8 x AOL-09-17(48.83 $\%)$ and AOL-09-17 x JOL-09-7(46.17 \%). Comparative studies of these three most heterotic crosses for fruit yield corresponding to other attributes are presented in table 3. In majority of the cases, these crosses also exhibited significant and desirable heterosis for days to initiation of flowering, Number of primary branches per Plant, Plant Height, Internodal Length, Fruit Length, Fruit 
Diameter and Number of Fruits per plant. High heterosis for fruit yield and its components in okra was also reported by Chauhan and Singh (2002), Kumar et al (2005), Borgaonkar et al., (2006), Desai et al., (2007), Dahake et al., (2007), Sriram et al., (2007), Hosamani et al., (2008), Khanpara et al., (2009), Dhabi et al., (2009), Kumar and Sreeparvathy (2010), Kumar et al., (2010), Jindal et al., (2010), Eswaran and Kumar (2013), Dayasagar (1994), Pathak et al., (2001), Sood and Kalia (2001), Kapadia (2002), Indurani et al., (2003), Amutha et al., (2007), Mehta et al., (2007), Ramya and Senthil Kumar (2010) and Wammanda et al., (2010).

The present study concludes that that these crosses HRB-55 x AOL-09-17, JOL-09-8 x AOL-09-17 and AOL-09-17 $x$ JOL-09-7 found to be most promising for fruit yield and other desirable traits, hence could be further evaluated in heterosis breeding programme and simultaneously could be advanced in segregating generations to obtain desirable segregants for the development of superior genotypes in okra genetic improvement.

\section{References}

Amutha, R., Venkatesan, M., Senthil Kumar, N. and Thangavel, P. 2007. Hybrid vigour and inbreeding depression in bhindi (Abelmoschus esculentus (L.) Moench). Agric. Sci. Digest, 27 (2): 131-33

Borgaonkar, S. B., Poshiya, V. K., Sharma, K. M., Savargaonkar, S. L. and Patil, M. 2006. Heterosis studies in okra [Abelmoschus esculentus (L) Moench]. International Journal of Plant Sciences. 1(2): 227-228.

Chauhan, S. and Singh, Y. 2002. Heterosis studies in okra [Abelmoschus esculentus (L.) Moench.] Veg. Sci., 29(2): 116118.
Dahake, K. D., Bangar, N. D., Lad, B. and Patil, H. E. 2007. Heterosis studies for fruit yield and its contributing characters in okra [Abelmoschus esculentus (L.) Moench.]. Internat. J. Plant Sci. 2(2): 137-140.

Desai, S. S., Bendale, V. W., Bhave, S. G. and Jadhav, B. B. 2007. Heterosis for yield and yield components in okra [Abelmoschus esculentus (L.) Moench.]. J. Maharashtra Agric. Univ. 32 (1): 041044.

Dhabi, K. H., Vachhani, J. H., Poshiya, V. K., Jivani, L. L., Vekariya, D. H. and Shekhati, H. G. 2009. International Journal of Agricultural Sciences. 5(2): 572-576.

Eswaran, R. and Thirugnana Kumar, S. 2013. Studies on the Heterotic Potential of Single and Three-way Cross Hybrids of Okra [Abelmoschus esculentus (L.) Moench.]. paripex - Indian Journal of Research. 2(1):1-3

Hosamani, R. M., Aajjappalavara, P. S., Patil, B. C., Smitha, R. P. and Ukkund, K. C. 2008. Heterosis for yield and yield components in okra. Karnataka J. Agric. Sci., 21(3): 473-475.

Indurani, C., Veeraragavathatham, D. and Auxeilia, J. 2003. Studies on the development of $\mathrm{F} 1$ hybrids in okra (Abelmoschus esculentus (L.) Moench) with high yield and resistance to yellow vein mosaic virus. South Indian Hort., 51(1-6): 219-26.

Jindal, S. K, Arora, D. and Ghai, T. R. 2010. Studies on heterosis for earliness in spring season okra [Abelmoschus esculentus (L.) Moench.]. SABRAO Journal of Breeding and Genetics. 42(2): $65-73$

Kapadia, S. I. 2002. Genetical studies in okra (Abelmoschus esculentus (L.) Moench). Unpublished Ph. D. thesis, G.A.U., S. K. Nagar. 
Khanpara, M. D., Jivani, L. L., Vachhani, J. H., Kachadia, V. H. and Madaria, R. B. 2009. Heterosis studies in okra [Abelmoschus esculentus (L) Moench]. International Journal of Agricultural Sciences. 5(2): 497-500.

Kumar, R., Yadav, J. R., Tripathi, P. and Tiwari, S. K.2005. Evaluating genotypes for combining ability through diallel analysis in okra. Indian J. Hort. 62(1): 88-90

Kumar Senthil, P. and Sreeparvathy, S. 2010. Studies on heterosis in okra [Abelmoschus esculentus (L.) Moench.]. Electronic Journal of Plant Breeding. 1(6): 1431-1433.

Mehta, N., Asatiand, B. S. and Mamidwar, S. R. 2007. Heterosis and gene action in okra. Bangladesh J. Agril. Res. 32(3): 421-432,

Pathak, R., Syamal, M. M. and Singh, A. K. 2001. Line x Tester analysis for yield and its components in okra
(Abelmoschus esculentus (L.) Moench). Ann. Agric. R.22 (1): 22-24.

Ramya, K. and Senthil Kumar, N. 2010. Heterosis and combining ability for fruit yield in okra (Abelmoschus esculentus (L.) Moench). Crop Improvement. 37(1): 41-45.

Sood, S. and Kalia, P. 2001. Heterosis and combining ability studies for some quantitative traits in okra (Abelmoschus esculentus (L.) Moench). Haryana J. Hort. Sci. 30(1-2): 92-94.

Sriram, P., Senthil kumar, P. and Karthikeyan, P. 2007. Level of heterosis and its use in okra breeding. Internat. J. Plant Sc. 2 (2): 38-41

Wammanda, D. T., Kadams, A. M. and Jonah, P. M. 2010. Combining ability analysis and heterosis in a diallel cross of okra (Abelmoschus esculentus (L.) Moench). African J. Agril. Res. 5 (16): 2108-15.

\section{How to cite this article:}

Tapas Paul, R.T. Desai and Choudhary, R. 2017. Genetical Studies on Assessment of Heterosis for Fruit Yield and Attributing Characters in Okra [Abelmoschus esculentus (L.) Moench]. Int.J.Curr.Microbiol.App.Sci. 6(6): 153-159. doi: https://doi.org/10.20546/ijcmas.2017.606.018 